\title{
Cleaning up of Contaminated Soils by Using Microbial Remediation: A Review and Challenges to the Weaknesses
}

\author{
Chee Kong Yap ${ }^{1 *}$ and Shih Hao Tony Peng ${ }^{2}$ \\ ${ }^{1}$ Department of Biology, University Putra Malaysia, Malaysia \\ ${ }^{2}$ All Cosmos Bio-Tech Holding Corporation, Pasir Gudang Industrial Estate, Malaysia
}

*Corresponding author: Chee Kong Yap, Department of Biology, Faculty of Science, Universiti Putra Malaysia, 43400 UPM, Serdang, Selangor, Malaysia. Email: yapckong@hotmail.com

To Cite This Article: Chee Kong Yap and Shih Hao Tony Peng. Cleaning Contaminated Soils by Using Microbial Remediation: A Review and Challenges to the Weaknesses. Am J Biomed Sci \& Res. 2019 - 2(3). AJBSR.MS.ID.000589. DOI: 10.34297/AJBSR.2019.02.000589

Received: March 01, 2019 | Published: April 10, 2019

\begin{abstract}
The use of microbial bioremediation in recovering polluted soils is not a new technology based on many review reports and studies on its efficiencies and on how to increase the effectiveness. In this short paper, we reviewed the advantages and weaknesses of microbial remediation in cleaning up the polluted ecosystems. Based on the identified weaknesses/disadvantages or incompleteness of the microbial remediation by Sharma and Reddy (2004), future studies should focus on how to increase the effectiveness of the bioremediation technology that should further reduce environmental stress on the terrestrial and aquatic ecosystems. Overall, strategies in the future studies for improving the microbial remediation are discussed.
\end{abstract}

Keywords: Microorganisms; Remediation; Microbes

\section{Introduction to Bioremediation}

Cleaning up of chemical pollutants from contaminated soils is a worldwide problem nowadays. The presence of elevated levels of chemical pollutants in the soil environment has contributed to soil pollution [1]. This is a potential threat to the ecosystem health that has a strong connection to the health of wildlife and human life quality ultimately.

The contaminated soils have been a result of

I. Mining of raw elements/materials,

II. Industrial waste due to production,

III. Vehicular transportation,
IV. Disposal or accidental spills of chemicals.

The use of bioremediation by using microorganisms have been found many in the literature [2-7]. Microbial remediation can be simply defined by employing microorganisms to lower the bioavailability of pollutants (especially organic contaminants) so as to make less toxic to the ecosystem. These microorganisms are capable to break down (or metabolize) contaminants by using them as a food source. Introduction of specific competent strains of microorganisms has been widely used in the bioremediation of soil pollution [8]. According to [6], bioremediation is an environmental friendly technology for cleaning up or recovering the polluted soils.

Table 1: Advantages of bioremediation over conventional/ traditional soil remediation methodologies.

\begin{tabular}{|c|c|c|}
\hline No. & Conventional/ traditional methods [1,3] & Bioremediation [8] \\
\hline 1 & Labour intensive; low efficiency & Not labour intensive; high efficiency \\
\hline 2 & Complete removal of pollutants is uncertain and unsure. & $\begin{array}{c}\text { Usually complete pollutant removal can be expected although not } \\
100 \% \text { compared to conventional methods. }\end{array}$ \\
\hline 3 & $\begin{array}{c}\text { Cause secondary pollution to the physical, chemical, and biological } \\
\text { characteristics of the treated soil }\end{array}$ & $\begin{array}{c}\text { Limited or no secondary pollution to the physical, chemical, and } \\
\text { biological characteristics of the treated soil. }\end{array}$ \\
\hline 4 & High cost of implementation & Low cost of implementation. \\
\hline 5 & Poor public acceptability & Perceived positively by the public. \\
\hline
\end{tabular}


According to [1], it is important to use suitable bioremediation technologies because of the site-specificity of most remediation methods. The weaknesses of conventional remediation technologies are presented in Table 1.

Based on Table 1, there are apparent advantages of using bioremediation when compared to conventional methods (Table 1). For example, the biodegradation by using bioremediation is non-invasive and cost-effective in the removal of Petroleum Hydrocarbon (PH) pollutants [9].

\section{Advantages and Disadvantages/Weaknesses of Microbial Remediation}

According to [10], the advantages and disadvantages/weaknesses of microbial remediation have been summarized in Table 2 .
According to a good review conducted by [11], the use of microbial remediation such as bacteria and fungi are useful for cleaning polluted soils. This is because the microbial remediation can effectively remove soil pollutants. From soil quality point of view, microbes can able to help limiting growth of plant pathogens, increasing nitrogen fixation, and causing lower bioavailabilities inorganic and organic pollutants in the soils. Microbe-assisted bioremediation (microbial remediation) offer many ecological and cost-associated benefits [5].

Challenges to the Weaknesses/Disadvantages of Microbial Remediation

Based on the weaknesses or disadvantages of microbial remediation in Table 2, five challenges can be highlighted:

\begin{tabular}{|c|c|c|}
\hline \multicolumn{2}{|c|}{ Table 2: Advantages and disadvantages/weaknesses of microbial remediation [10]. } \\
\hline No. & $\begin{array}{c}\text { Advantages } \\
\text { Possible to fully breakdown organic contaminants into other } \\
\text { nontoxic chemicals }\end{array}$ & $\begin{array}{c}\text { Presence of incomplete breakdown of organic contaminants if the } \\
\text { process is not well controlled, managed and monitored. }\end{array}$ \\
\hline 2 & $\begin{array}{c}\text { Requirement of minimal equipment when compared to other } \\
\text { remediation technologies. }\end{array}$ & $\begin{array}{c}\text { The process is sensitive to the level of toxicity and physico-chemical } \\
\text { conditions in the soils. }\end{array}$ \\
\hline 3 & $\begin{array}{c}\text { Methods of in-situ or ex-situ can be used method depending on } \\
\text { conditions of the soils. }\end{array}$ & $\begin{array}{c}\text { Monitoring to check the rate of biodegradation (or efficiency) of the } \\
\text { organic contaminants in the field removal is necessary. }\end{array}$ \\
\hline 4 & $\begin{array}{c}\text { Low cost of treatment per unit volume of soil when compared } \\
\text { to other remediation methods. }\end{array}$ & $\begin{array}{c}\text { Controlling volatile organic compounds (VOCs) is not easy if ex-situ } \\
\text { method is used. }\end{array}$ \\
\hline 5 & Low-technology equipment is required. & $\begin{array}{c}\text { Treatment time of the polluted soils is longer than other remediation } \\
\text { technologies. }\end{array}$ \\
\hline 6 & Positive acceptance by the public because it is a natural process. & This treatment is usually limited to biodegradable compounds. \\
\hline
\end{tabular}

To decrease the bioavailability of incomplete breakdown of pollutants

Since there is possibility of incomplete breakdown of organic pollutants by using microbial remediation, the challenge is to study a complete breakdown of those contaminants. If complete breakdown of these pollutants is not possible, the bioavailability of these pollutants should be decreased. Studies should continue to increase the effectiveness of the microbial remediation technology. This includes how to control the processes so that the organic contaminants can be fully metabolized. This is important to immobilize and to reduce the bioavailability of the organic contaminants in the soils. [12] found that linear correlations between the Total Petroleum Hydrocarbons (TPH) and alkane degradation rates and the population and activity increases of TPH and alkane degraders (microbes). [9] critically reviewed the bioavailability of the pollutants during the degradation of $\mathrm{PH}$ process by microorganisms [13] reviewed the commercially available microbes in the bioremediation depending on factors affecting the biodegradation process of $\mathrm{PH}$ [13].

\section{More studies on specific species of fungal and bacteria should be documented}

Specific species of fungal and bacteria should be investigated so that the process involving these microbes are tolerant and insensitive to the levels of toxicity of the environmental soils. From a review by [8], they mentioned successful bioaugmentation of aromat- ics-contaminated soils by single strains or mixed consortia. Regular application of herbicides may lead to their accumulation in the soil and at elevated concentration changes the physico-chemical properties of soils, microfloral composition and their activities and consequently the crop yields [2]. Microbial remediation is related to relationship of plant-bacteria that is applied to improve crop yield [14]. This plants obtain benefits from their associated-bacteria that possess the capability to biodegrade hydrocarbon. This enhances lower bioavailability of PH in terms of phytotoxicity and evapotranspiration of volatile hydrocarbons. Synergistic response between relationship of plants and microbes is recognized as an effective in situ method to clean up the polluted soils [7].

\section{Regular monitoring of the effectiveness of microbial re- mediation is needed}

Regular check and field biomonitoring of the rate of biodegradation of PH by the microbes should be conducted to reduce the unmobilized organic contaminants to be leached into the ground. If an ex-situ process is used, methodologies on how to control problematic volatile organic compounds (VOCs) in the soils should be provided based on field and laboratory studies. Since incomplete breakdown of pollutants into non-toxic compounds is sometimes possible, the persistent and toxic residual levels should be managed properly to reduce further environmental problems to the terrestrial and aquatic ecosystems. This could result in toxic by-products in the soil that could be more mobile and toxic when compared to the initial contamination. 
If an ex-situ method is used in the microbial remediation, monitoring and controlling volatile organic compounds (VOCs) is not easy [10]. Therefore, field monitoring of VOCs on the efficiency of microbial remediation is necessary.

\section{Shorter treatment period of microbial remediation}

Although low-technology equipment is required, treatment time could be shorter. This could involve genetically engineered microorganisms for the microbial remediation. The efficiency of microbial remediation can be improved by genetically modified microbes [5]. Hence, further studies on the biodegradation process by the microbes are needed. Enhancement of bioremediation technologies by using transgenic plants and microbes has also been reviewed by [15]. This is important in the mitigation of associated ecological risk assessments of the polluted soils.

\section{Microbial remediation should include a wider range of contaminant clean up}

Future studies should focus on wider range of contaminants that can be effectively treated. These compounds that to be metabolized and degraded should include those of non-biodegradable in addition to biodegradable pollutants. Although the advantages of microbial remediation include minimal secondary pollution and preservation of topsoil quality [3], the usefulness in treating a broad range of environmental contaminants is questionable. [4] focused on phytoremedial plants that are able to deal with this type of complex pollution. This involves not only species that tolerate the joint effect of heavy metals in the soil, but also those that can take advantage of associated bacteria to efficiently break down organic compounds.

This has been the subject research area of [4] who focussed on phytoremedial plants that can tolerate the combination effects of heavy metals in the soil, in addition to the advantage of associated bacteria that can efficiently break down organic compounds in the soils.

\section{Concluding Remarks}

The use of microbial bioremediation in recovering polluted soils is not a new technology based on many review reports and studies on its efficiencies and on how to increase the effectiveness. Based on the above-mentioned six weaknesses/disadvantages of the microbial remediation by [10], future studies should focus on how to increase the effectiveness of the bioremediation technology that should further reduce environmental stress on the terrestrial and aquatic ecosystems. These challenges should be considered a trial and error research niche in the betterment of microbial remediation technology in future studies.

\section{References}

1. Hussain I, Aleti G, Naidu R, Puschenreiter M, Mahmood Q et al. (2018) Microbe and plant assisted-remediation of organic xenobiotics and its enhancement by genetically modified organisms and recombinant technology: A review. Sci Tot Environ 628-629: 1582-1599.

2. Ahemad M, Khan S, Zaidi A, Parvaize W (2009) Remediation of herbicides contaminated soil using microbes. Microbes in Sust Agr pp. 261-284.

3. Das M, Adholeya A (2011) Role of microorganisms in remediation of contaminated soil Microorg. Environ Manage pp. 81-111.

4. Gutiérrez Ginés MJ, Hernández AJ, Pérez-Leblic MI, Pastor J, Vangronsveld J (2014). Phytoremediation of soils co-contaminated by organic compounds and heavy metals: Bioassays with Lupinus luteus L. and associated endophytic bacteria. J Environ Manage 143: 197-207.

5. Chen M, Xu P, Zeng G, Yang C, Huang D et al. (2015) Bioremediation of soils contaminated with polycyclic aromatic hydrocarbons, petroleum, pesticides, chlorophenols and heavy metals by composting: Applications, microbes and future research needs. Biotech Adv 33(6): 745-755.

6. Agnello AC, Bagard M, van Hullebusch E D, Esposito G, Huguenot D (2016) Comparative bioremediation of heavy metals and petroleum hydrocarbons co-contaminated soil by natural attenuation, phytoremediation, bioaugmentation and bioaugmentation-assisted phytoremediation. Sci Tot Environ 563-564: 693-703.

7. Feng NX, Yu J, Zhao H M, Cheng YT, Mo CH et al. (2017) Efficient phytoremediation of organic contaminants in soils using plantendophyte partnerships. Sci Tot Environ 583: 352-368.

8. Xu Y, Zhou NY (2017) Microbial remediation of aromatics-contaminated soil. Frontiers Environ Sci Eng 11: 1.

9. Varjani SJ, Upasani VN (2017) A new look on factors affecting microbial degradation of petroleum hydrocarbon pollutants. Int Biodeter Biodegr 120: 71-83.

10. Sharma HD, Reddy KR (2004) Geo-Environmental Engineering: Site Remediation, Waste Containment and Emerging Waste Management Technologies, John Wiley, New Jersey, USA.

11. Bakshi P (2014) The use of microbes for soil remediation.

12. Wu M, Li W, Dick WA, Ye X, Chen K et al. (2017) Bioremediation of hydrocarbon degradation in a petroleum-contaminated soil and microbial population and activity determination. Chemosphere 169: 124-130.

13. Varjani SJ (2017) Microbial degradation of petroleum hydrocarbons. Biores Technol 223: 277-286

14. Khan S, Afzal M, Iqbal S, Khan QM (2013) Plant-bacteria partnerships for the remediation of hydrocarbon contaminated soils Chemosphere 90(4): 1317-1332.

15. Hussain I, Puschenreiter M, Gerhard S, Schöftner P, Yousaf S (2018) Rhizoremediation of petroleum hydrocarbon-contaminated soils: Improvement opportunities and field applications. Environ Exp Bot 147: 202-219. 